\title{
STUDIES ON THE MORPHOLOGICAL, THERMAL AND RESISTIVITY PROPERTIES OF RECYCLED POLY (ETHYLENE TEREPHTHALATE) COMPOSITES WITH NANOCLAY FILLERS
}

\author{
S.Rajarajan ${ }^{1}$, J.Raja $^{2}$ \\ ${ }^{1}$ Research Scholar, Sathyabama University, Jeppiaar Nagar, Chennai-600 119. \\ ${ }^{2}$ Professor and Head/IT, SSN College of Engineering, Kalavakkam, Chennai-603 110.
}

\begin{abstract}
Nanocomposites based on polymer-clay mixtures are a growing area of interest due to their potential in flexible applications. In this study, new nanocomposite materials were produced from the components of recycled thermoplastic as the matrix and montmorillonite as the filler by using a co-rotating twin screw extruder. During this study, recycled Poly(Ethylene Terephthalate), $\mathrm{rPET}$, was mixed with organically modified quaternary alkyl ammonium montmorillonite in the contents of 1,2 , and 5 weight $\%$. Three types of clays were evaluated during the studies. For comparison, 2 weight $\%$ clay containing samples were prepared with three different clay types, Cloisite 15A, 25A, 30B.Even though, 2wt \% Cloisite25A shows better mechanical properties, $2 \mathrm{wt} \%$ Cloisite $30 \mathrm{~B}$ is better in respect of electrical properties.
\end{abstract}

Key words: Nanocomposite, Thermoplastic Nanocomposites, rPET, Montmorillonite.

\section{INTRODUCTION}

Polymer layered silicate nanocomposites have become an important area studied more widely in academic, government and industrial laboratories. These type of materials were first reported as early as 1950, [1]. However, it was not widespread until the period of investigation on this type of structures by Toyota researchers, [2-5]. This early work of Toyota group was based on the formation of nanocomposites where montmorillonite was intercalated with $\varepsilon$-caprolactam in situ. Polymeric materials can be filled with several inorganic and/or natural compounds in order to get the wide array of property enhancements, e.g, increased stiffness and strength, improved solvent and UV resistance, greater dimensional stability, decreased electrical conductivity, enhanced gas barrier properties. The property improvements of clay based nanocomposites are due to the nanoscale nature of the formed system resulting in very high surface areas.

From an industrial approach, owing to high costs of development, synthesis and commercialization of new polymers, most researchers look for new materials by reinforcing or blending existing polymers, so the tailor made properties of the materials can be achieved, [6]. Poly(Ethylene Terephthalate) (PET) is a low-cost, and high performance thermoplastic that finds use areas in a variety of applications, such as in fabrics and soft drink bottles, reinforcement of tyres and rubbery goods, food and beverage packaging. PET has excellent surface characteristics, and high heat deflection temperature. PET regrinds from post consumer soft drink bottles have slightly reduced molecular weight and structure related properties as compared to pure polymer.

In this study, the aim is to produce nanocomposite materials from recycled PET regrinds as the matrix with the addition of organically Modified Montmorillonite (MMT) clays as the filler, and observe the effects of clay content and clay type on sample properties, like thermal, morphological and resistivity .

\section{MATERIALS}

\section{A. Organoclays}

Experiments were carried out with three different types of montmorillonites, namely Cloisite 30B, 15A, and $25 \mathrm{~A}$. These organoclay structures show differences in selection according to what degree of polarity they have. There is an increase in relative product hydrophobicity and a decrease in product polarity in the order of $30 \mathrm{~B}, 25 \mathrm{~A}$, and 15A. Thus, the hydrophobicity resulted from different natures of organic modifiers affects the chemical compatibility between the polymer and the filler.

Following sections describe the product properties of these clay types. Cloisite30B is a montmorillonite modified with a ternary ammonium salt, whereas Cloisite $15 \mathrm{~A}$ and Cloisite25A are montmorillonite modified with a quaternary ammonium salts.

\section{TABLE 1 Properties of Organoclays}

\begin{tabular}{|c|c|c|c|}
\hline $\begin{array}{ll}\text { TREATME } \\
\text { NT/ } \\
\text { ES }\end{array}$ & $\begin{array}{r}\text { CLOI } \\
\text { SITE } 30 B\end{array}$ & $\begin{array}{l}\text { CLOI } \\
\text { SITE 15A }\end{array}$ & $\begin{array}{r}\text { CLOI } \\
\text { SITE 25A }\end{array}$ \\
\hline $\begin{array}{l}\text { Organic } \\
\text { Modifier }\end{array}$ & $\begin{array}{c}\text { M T2 } \\
\text { EtOH }\end{array}$ & $\begin{array}{l}2 \mathrm{M} 2 \mathrm{H} \\
\mathrm{T}\end{array}$ & $T L 8^{2 \mathrm{MH}}$ \\
\hline \begin{tabular}{l}
\multicolumn{1}{c}{ Cation } \\
Exchange \\
Capacity (CEC)
\end{tabular} & $\begin{array}{c}90 \\
\mathrm{meq} / 100 \mathrm{~g}\end{array}$ & $\begin{array}{c}125 \\
\mathrm{meq} / 100 \mathrm{~g}\end{array}$ & $\begin{array}{c}95 \\
\mathrm{meq} / 100 \mathrm{~g}\end{array}$ \\
\hline$\%$ Moisture & $<2 \%$ & $<2 \%$ & $<2 \%$ \\
\hline $\begin{array}{l}\% \text { Weight } \\
\text { Loss on Ignition }\end{array}$ & $30 \%$ & $43 \%$ & $34 \%$ \\
\hline $\begin{array}{l}\text { Density, } \\
\mathrm{g} / \mathrm{cc}\end{array}$ & 1.98 & 1.66 & 1.87 \\
\hline
\end{tabular}




\section{B. PETResin}

PET soft drink bottle regrind was obtained in the form of flakes with the following general physical properties.

TABLE 2 Contaminants in Recycled PET Resin

\begin{tabular}{|c|c|}
\hline $\begin{array}{ll} & \text { CONTAMINANT } \\
\mathrm{S} & \end{array}$ & $\begin{array}{l}\text { VALUE } \\
\text { (PPM) }\end{array}$ \\
\hline PVC & 60 \\
\hline Polyethylene & 5 \\
\hline Metal pieces & 0 \\
\hline Adhesive & 10 \\
\hline Paper pieces & 3 \\
\hline
\end{tabular}

TABLE 3 Properties of Recycled PET Resin

\begin{tabular}{|c|c|}
\hline MATERIAL PROPERTIES & VALUE \\
\hline \multirow{2}{*}{ Intrinsic Viscosity, [n] } & 0.750 \\
\hline & $\mathrm{g} / \mathrm{cm} \cdot \mathrm{s}$ \\
\hline $\begin{array}{cc}\text { Glass } & \text { Transition } \\
\text { Temperature, } \mathrm{Tg} & \end{array}$ & $60^{\circ} \mathrm{C}$ \\
\hline Melting Temperature, Tm & $\begin{array}{l}255^{\circ} \mathrm{C}- \\
260^{\circ} \mathrm{C}\end{array}$ \\
\hline
\end{tabular}

\section{PREPARATION OF NANOCOMPOSITE SPECIMENS}

In the preparation of nanocomposite materials, the following steps shown in Fig. 1 were carried out.

\section{A. Drying}

Because of the sensitivity of PET towards degradation by moisture, the resin was dried for 4 hours in a vacuum oven at $170 \mathrm{oC}$. The organo-clay capable of absorbing moisture was dried 4 hours at $120 \mathrm{oC}$. Before each injection molding process, the products needed to be dried in a vacuum for 4 hours at $120 \mathrm{oC}$.

\section{B. Extrusion}

The ingredients were fed into the extruder barrel at previously determined speed of the feeders. The screw speed of the extruder was adjusted to $150 \mathrm{rpm}$, while other parameters were kept constant. Four temperature zones were adjusted and controlled for each extrusion process, optimum operating was obtained when the zone temperatures were kept at $275,275,275,250 \mathrm{oC}$ in melting, mixing, metering, and feeding sections, respectively. The die temperature was kept at $280 \mathrm{oC}$ in each extrusion process. The extrudates were cooled by water at the exit of the die, and then air-cooled, chopped, and stored until the molding process. Materials were vacuum dried for 4 hours at $120 \mathrm{oC}$ before each molding process to avoid the effects of moisture.

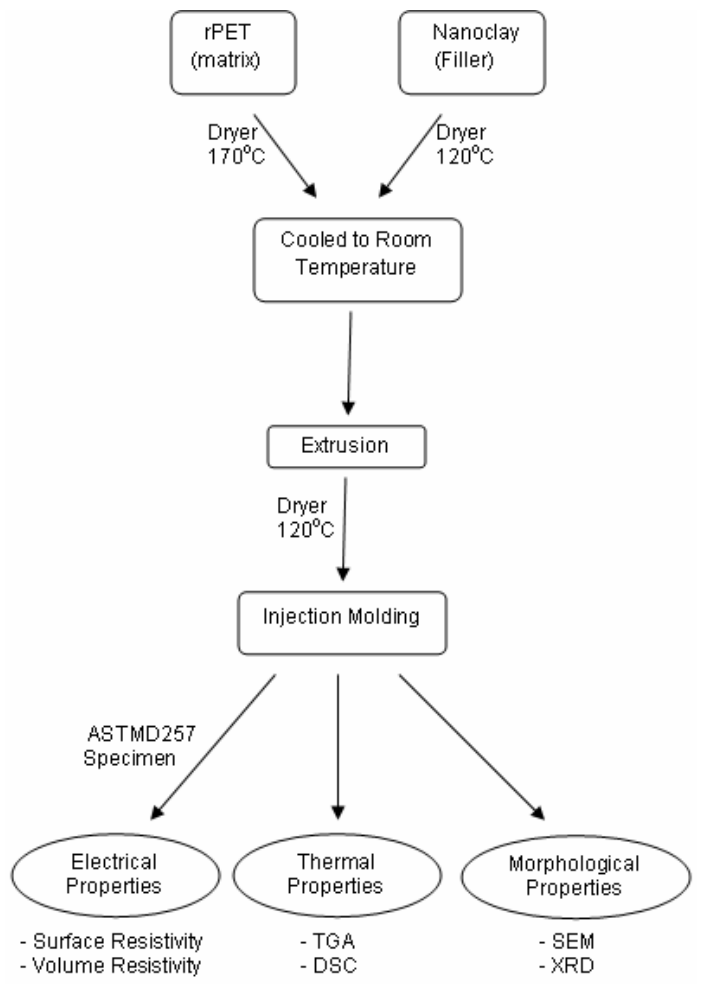

Fig.1. Flowchart of nanocomposite specimen preparation, and types of characterization methods used.

\section{Injection Molding}

Keeping the temperature of the injection nozzle constant at $2750 \mathrm{C}$ previously extruded and chopped samples of R-PET/organoclay blends were injection molded. Adjustments in mold fill time (3-8 sec), molding cycle time (3-5 $\mathrm{min}$ ), and holding pressure (6-8.5 bars) were made in order to obtain the best-molded part appearance for each composition. Optimum values were $3 \mathrm{sec}$ for fill time, 3 min for cycle time and 8.0 bars for holding pressure. The samples obtained at the end of these production steps were analyzed and tested according to ASTM Standards.

\section{RESULTS AND DISCUSSION}

\section{A. Morphological Studies}

In fig.2, the fracture surface of recycled-PET (neat resin) is shown. There are long, distant, and wider crack propagation lines, due to the heterogeneous nature of the structure, including contaminants such as PVC, metal pieces, polyethylene etc. Except for polyolefin contaminants, they act as stress concentrators on the sample surface. 


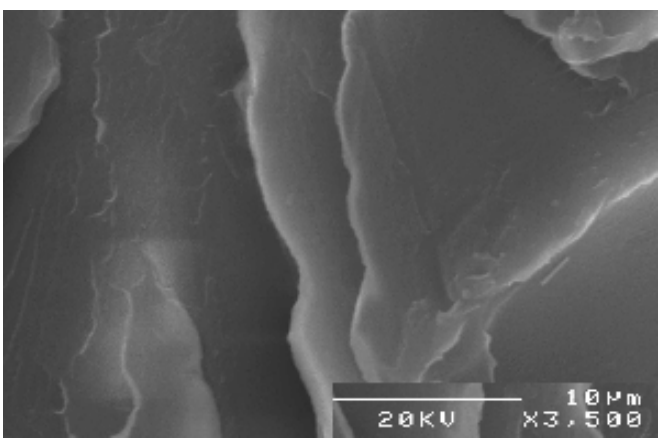

Fig.2 SEM of recycled-PET neat Resin

Fig. 3,4 and fig. 5 shows the fracture surfaces of samples containing 1,2 , and 5 weight $\%$ of Cloisite 30B. In these photos, the main difference is the dispersion of the clay platelets. Due to the nature of high clay loading, 5-weight \% sample exhibits a structure having large clay aggregates, which act as stress concentrators. This causes localized stresses on the surface of the clay leading to worse impact strength. In sample with 1 weight \% clay, long crack propagation lines and clay aggregates, small white objects on the photo, can be observed. In comparison with the sample with 2-weight \% clay loading, the surface looks smoother implying easier crack propagation. 2 weight \% one has more tortuous structure preventing easy crack propagation.

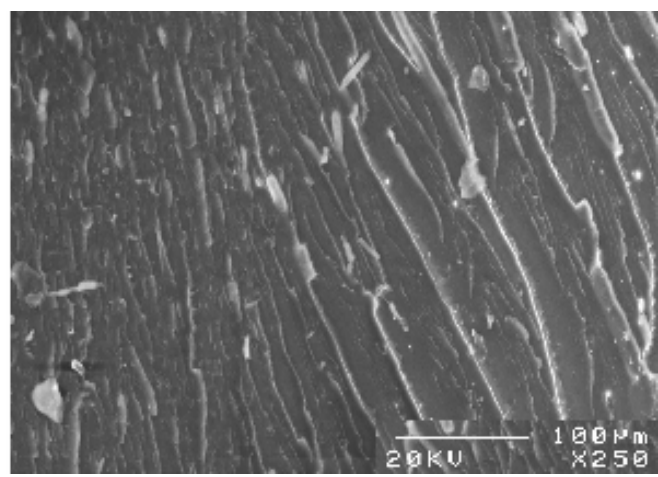

Fig. 3 SEM of recycled-PET+ 1 wt \% Cloisite 30B

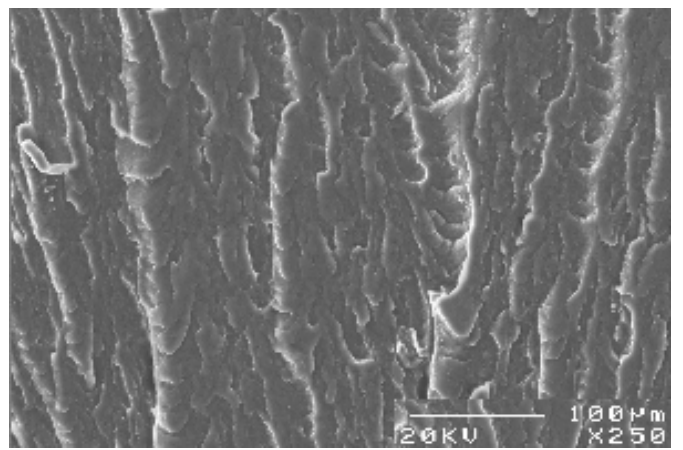

Fig.4 SEM of recycled-PET+ 2 wt \% Cloisite 30B

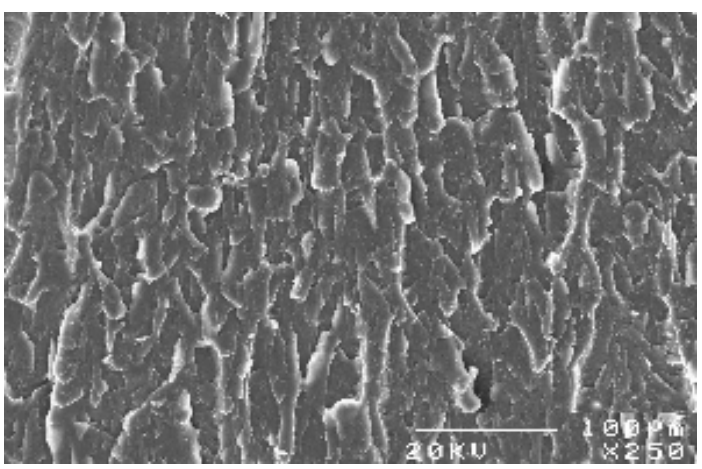

Fig.5 SEM of recycled-PET+ 5 wt \% Cloisite 30B

When compare the samples containing 2 weight \% of 30B (Fig.4), 2 weight \%of 15A (Fig.6) and 2 weight \%of 25 A(Fig.7) clay types, it is observed that smaller distances between crack propagation lines and more disperse and tortuous characteristic in the composition containing 30B clay type. But, this structure gives lower impact energy than the one containing $25 \mathrm{~A}$ clay type. The reason could be that, in the samples of $30 \mathrm{~B}$ adhesion strength between the matrix and the filler may not be as good as the samples containing $25 \mathrm{~A}$ montmorillonite, thus cracks in samples with $30 \mathrm{~B}$ may need lower energy to propagate in spite of better dispersion. 15A samples give the lowest impact energy.

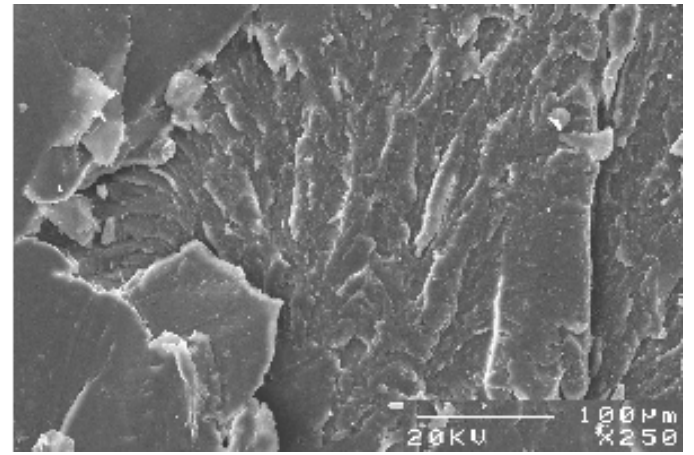

Fig.6 SEM of recycled-PET+ 2 wt \% Cloisite 15A

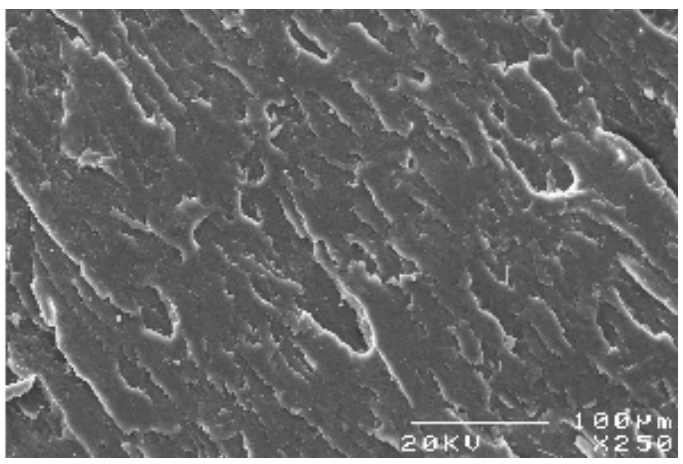

Fig.7 SEM of recycled-PET+ 2 wt \% Cloisite 25A

\section{B. Thermal Studies}

Differential scanning calorimeter analysis was performed in 
order to evaluate the changes in Glass Transition temperature $(\mathrm{Tg})$ with increasing clay content. Glass transition temperature is largely related to the molecular mobility of polymer chains.

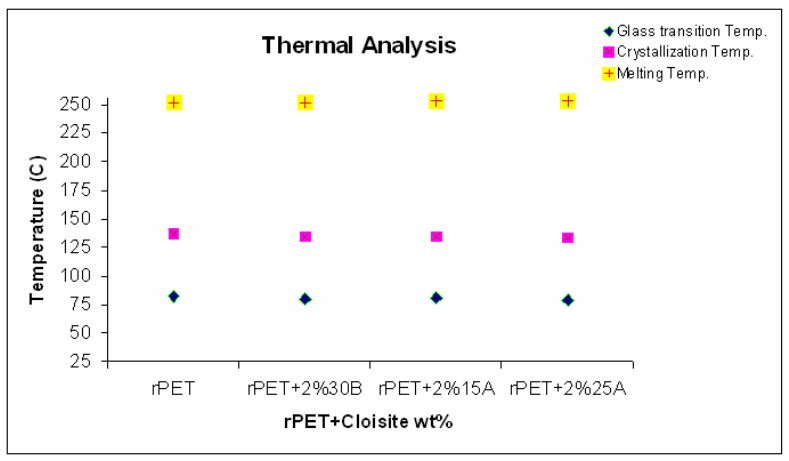

Fig.8 Thermal Analysis of resultant Nanocomposites

The crystallization (Tc) and melting temperatures (Tm) do not change as much with the clay type and clay content, indicating that the rearrangement capability of the chains into crystals are not much affected.

\section{Resistivity Studies}

Resistivity tests were conducted using ASTMD257 samples for both volume resistivity and surface resistivity.

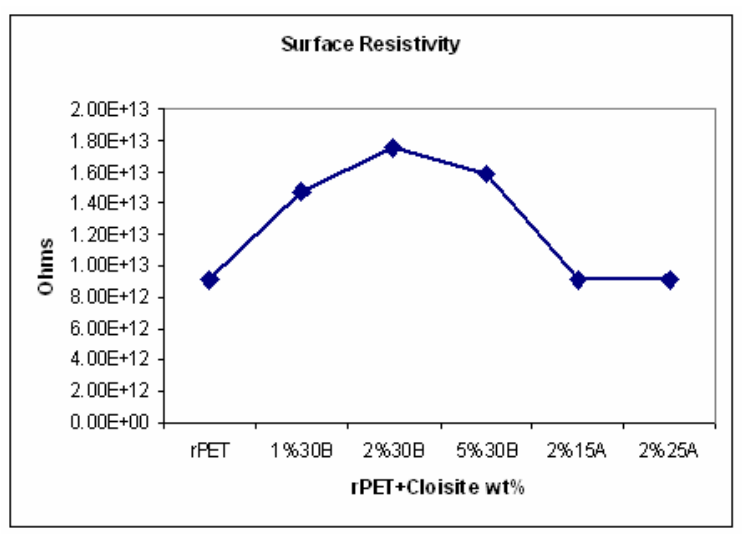

Fig.9 Surface Resistivity of resultant Nanocomposites

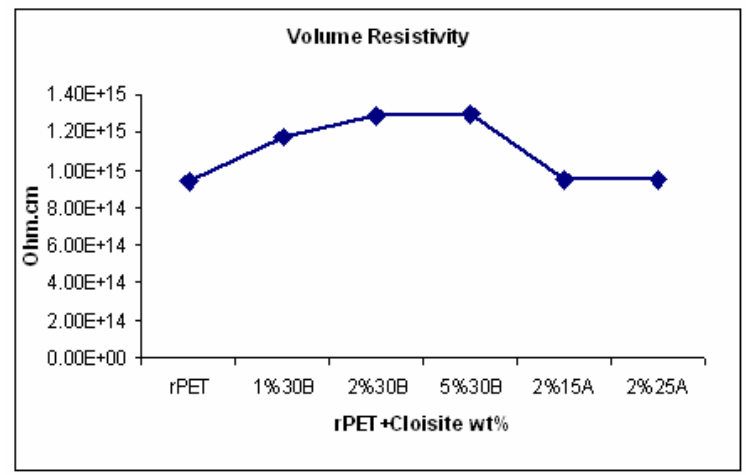

Fig.10 Volume Resistivity of resultant Nanocomposites
According to the results, 2 weight $\% 30 \mathrm{~B}$ yields better resistivity than other two $15 \mathrm{~A}$ and $25 \mathrm{~A}$ clay blends. This shows obviously the material structure plays a vital role in determining the resistivity of polymer nanocomposites. As a whole, intercalation or exfoliation of the nano-filler into the rPET matrix decides the resistivity.

\section{CONCLUSION}

Based on SEM, the main differences between the structures due to the dispersion of clay particles, and the compatibility of montmorillonite types with the recycled PET base resin. It is observed that the most tortuous path was there at 2 weight $\%$ clay loading implying the highest degree of dispersion and exfoliation. At lower clay content (1\%), the amount of clay was not enough to improve the properties. At higher clay content $(5 \%)$, the clay remained mostly as aggregates giving rise to poor properties. Among the clay types, generally the 25A type of montmorillonite produced the highest tortuous structure in SEM micrographs. The tortuous surface, small and the heterogeneous crack propagation pathways on micrographs are the evidence of exfoliation of silicate layers in the matrix implying enhancements both in physical and thermal properties.

DSC analysis showed that the incorporation of clay particles into the base polymer caused changes in $\mathrm{Tg}$ values. The maximum increase in $\mathrm{Tg}$ values was observed in the sample containing 2 weight $\%$ of 25A clay type. The Tg increased from $81.80 \mathrm{C}$ (value of $r-P E T$ ) to $83.20 \mathrm{C}$.

Resistivity results shows 2 weight $\% 30 \mathrm{~B}$ clay type is better for dielectric application. Since,SEM studies and DSC studies are favourable for 2 weight $\% 25$ A clay type, this clay and composition may be good mechanically, whereas resistivity tests prefer 2 weight $\% 30 \mathrm{~B}$ clay as a good electrical insulator.

\section{REFERENCES}

[1] Dennis H.R., Hunter D.L., Chang D., Kim S., White J.L., Cho J.W. and Paul D.R. Polymer, 2001 - 42, 9513-9522

[2] Kojima Y., Usuki A., Kawasumi M., Okada A., Kurauchi T., and Kamigaito O., J. of Appl. Polym. Sci., 1993 - 31, 983-986

[3] Yano K., Usuki A., Okada A., Kurauchi T., and Kamigaito O., International Journal of Polymer Science: Part A: Polymer Chemistry, 1993- 31, 2493-2498

[4] Kojima Y., Usuki A., Kawasumi M., Okada A., Kurauchi T., and Kamigaito O., J. 1993 - of Appl. Polym. Sci., 49, 1259-1264

[5] Messersmith P.B., and Giannelis E.P.(1995)., 
International Journal of PolymerScience: Part A: Polymer Chemistry, 33, 1047-1057.

[6] Guozhen Z., Shichi T. and Takagi K.,2000. Materials Letters, 4077, 1858-1862

[7] Schwartz M., 19,97 'Composite Materials', Prentice Hall PTR, Upper Saddle River, N.J., USA, Vol.1.

[8] Lubin G.,1982 'Handbook of Composites', Van Nostrand Reinhold, New York.

[9] Strong A B.1993., 'High Performance and Engineering Thermoplastic Composites', Technomic Pub. Co., Lancaster, Pennsylvannia.

[10] Matthews F.L., R.D. Rawlings1994, 'Composite Materials; Engineering and Science', Chapman\&Hall, London, NewYork.

[11] Announcement of Media Briefing, 'Nanotechnology, the next industrial revolution? Nanotechnology in the EU and US', Tolouse Conference (FR), 19.0ct.2000.

[12] A web page of the Southern Clay Products, www.southernclayproducts.com

[13] Bower C.A., lowa Agricultural Experiment Station Research Bulletin, 362, 39 (1949).

[14] Blumstein A., Bull. Chim. Soc., 889 (1961).

[15] Giannelis E.P., 'Polymer/Layered-silicate Nanocomposites (PLSNs), An internet paper, ww w. c c m r. cornell. edu/ giannelis/research/silicate.html.

[16] Zanetti M., Lomakin S., Camino G., Macromol. Eng., Vol.279, 1-9,2000.

[17] Lanie R.M., Choi J., and Lee I., Advanced Materials, Vol.13, No. 11, 800-803, (2001).

[18] Brechet Y., Cavaille J.Y., Chabert E., Chazeau L., Dendievel R., Flandin L, and Gauthier C., Advanced Engineering Materials, Vol.3, No. 8, 571-577 (2001).

[19] Manias E., 'Origins of the Materials Properties Enhancements in Polymer/Clay Nanocomposites', http://zeus.plmsc.psu.edu/nano.html

[20] Fornes T.D., Yoon P.J., Keskkula H., and Paul D.R., Polymer ,2001 , 42, 9929-9940.

[21] Wypych J.G., 'Fillers', Chem. Tech. Publishing, Toronto, 199).

[22] Velde B., 'Origin and Minerology of Clays: Clays and the Environment', Springer, NewYork, 1995.

[23] Haydn H.M., 'Clays: Survey', Kirk-Othmer
Encyclopedia of Chemical Technology, John Wiley\&Sons, Inc. NewYork ,2002.

[24] Grim R.E., 'Clay Minerology', 2nd Edition, McGrawHill Inc., NewYork, USA, 1968.

[25] Billmeyer F.W., 'Textbook of Polymer Science', 3rd Edition, John Wiley\&Sons, NewYork, 1984.

[26] Martinez J.M., Eguiazabal J.I., and Nazabal J., J. Macromol. Sci.-Phys., B34 (1\&2), 171-176, 1995).

[27] Raunwendaal C., 'Polymer Mixing: A Self-Stdy Guide', Hanser Publishers, NewYork, 1992.

[28] Raunwendaal C., 'Polymer Extrusion', 3rd Edition, Hanser/Gardner Publishers, NewYork, ,1994.

[29] Vaia R.A. and Giannelis E.P. Macromolecules, 30, 8000-8009,1997.

[30] Davis C.H., Mathias L.J, Gilman J.W., Schiraldi D.A., Shelds J.R., Trulove P., Sutto T..E., and Delong H.C., J. Polym. Sci. Part B: Polymer Phys., 40, 2661-2666,2002.

[31] Burillo G., Clough R.L., Czvikovszky T., Guven O., Le Moel A., Liu W., Singh A., Yang J., and Zaharescu T., Radiation Physics and Chemistry, 64, 41-51, 2002.

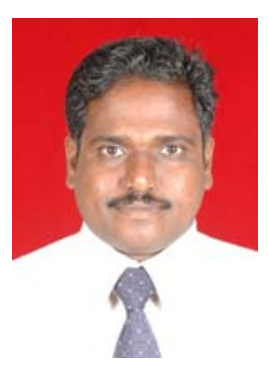

S.RAJARAJAN graduated from Mohammed Sathak Engineering College, Kilakarai during the year 1991 in Electronics and Communication Engineering Discipline. He obtained his Master's degree during the year 2002 with the specialization in Applied Electronics from Sathyabama Institute of Science and Technology, Chennai. He is doing his research work in the field of NanoElectronics. Currently he is the Assistant Professor, in the department of Electronics and Communication Engineering of Sathyabama university, Chennai-600 119. He has published about 17 papers to his credit in National and International Conferences. He has guided about 12 M.E./M.Tech. projects so far. 